\title{
RECONSTRUCTING SUBJECTIVE STUDY EXPERIENCES DURING SHUTDOWN IN PANDEMIC TIMES
}

\author{
Laura Eigbrecht, Ulf-Daniel Ehlers, Baden-Wurttemberg Cooperative State University \\ Karlsruhe, Germany
}

\section{Abstract}

The article reports on a qualitative study based on interviews with students systematically conducted online since March 2020. A total of 13 individual and eleven group interviews on the personal study situation during the Corona shutdown have been conducted, analysed and evaluated. The students' perspectives provide insights into how they subjectively reconstruct and classify the experiences they have made, what conclusions can be drawn from this for future higher education and how higher education institutions must evolve in order to support students in the best possible way. In addition to numerous challenges, the pandemic has brought forth the potential of students to shape and reflect on their learning processes in a self-determined and self-organised way and to contribute as experts to shaping the future of higher education.

\section{Introduction}

The Corona Shutdown has challenged students in higher education institutions to adapt to a local shift of study from the campus to their own homes and an almost complete digitisation of teaching in the form of distance learning modes. In the process, the Corona pandemic has placed higher education institutions in one of the largest field trials to date in the area of new teaching-learning methods (Nascimbeni \& Ehlers, 2020; p.II). While the situation of teachers was addressed immediately after the shutdown occurred in the form of support measures, this happened little with the situation of students in the public discourse at first. Larger empirical studies that focus on the students' perspective have been released towards the end of 2020 and feature primarily quantitative, standardised approaches (e.g. Marczuk et al., 2021; Traus et al., 2020; Gestung et al., 2021). In order to classify the new study situation beyond quantitative parameters, this article analyses the results of interviews with students that have been conducted systematically since the beginning of the pandemic, constituting a qualitative-explorative approach to the students' situation. 
The aim was to find out how students experience their studies during the shutdown in terms of their abilities and the prevailing framework conditions, how they organise their studies and learning themselves, and what potentials and challenges they see for (future) higher education. For this purpose, students have been interviewed since March 2020 and asked about their study experiences during the Corona shutdown. Parts of the interviews were also published as podcasts and represent the most comprehensive podcast series to date on the situation of students during the Corona period throughout Europe (nextnormal.eu and studium-im-shutdown.de). The data provides insights into how students subjectively reconstruct the experiences they had. The qualitative approach is particularly suitable for describing and analysing subjective study experiences. In the second chapter, the research methodology and the research questions are described, and in the third chapter the results are presented and analysed and then summarised.

\section{Research Methodology}

The study follows a qualitative design based on online interviews with students. Our qualitative approach focuses particularly on strategies with which students react to the new situation of studying in the shutdown.

\section{Research question}

The study is about investigating subjective learning and study preferences that students perceive and describe with regard to their study situation during the shutdown. The main open question is: how do students experience their studies during the shutdown in terms of their abilities and in terms of the prevailing framework conditions in order to organise their studies and learning themselves, and which study and learning strategies do they have or develop? The aim is to investigate whether and how students deal with the new study situation not only in the sense of reactive "coping" (see, for example, Grabowski et al., 2007; pp.674 ff.), but in the sense of a subjectively productive approach (as suggested, for example, by subjective learning and socialisation theories, see Ehlers (2004) for a summary), and how the subjective reconstructions provide indications of study opportunities and support needs that can be of importance for the organisation of studies during the shutdown. The main question is concretised in three sub-questions:

1. From the students' perspective, what are the preferences and quality requirements for higher education teaching in the shutdown?

2. How do students describe their participation opportunities and requirements in higher education teaching in the shutdown?

3. How do students in the Corona Shutdown describe and reconstruct their own study strategies, especially with regard to self-organisation and self-regulation? 


\section{Research Design}

The qualitative interviews have been conducted and recorded as a Zoom conference since March 2020 with German students as well as with students from various European countries. For this purpose, students were interviewed in semi-structured, guideline-based individual and group interviews lasting up to 80 minutes about their study situation during the Corona Shutdown. The digital recordings were coded using the data analysis software MAXQDA according to the method of qualitative content analysis (Mayring, 2015). Beforehand, a code tree was generated in a theory-based procedure in order to be able to work out the subject-related subjective assessment of the students.

\section{Sample selection, interview situation and limitations}

The interviews were conducted from two weeks after higher education institutions had to switch to an online teaching mode. Some of them were made available to the public as podcasts, which had two objectives: to gain insights into the situation of students with regard to the above-mentioned questions and to give students a voice in the public discussion, to describe their current situation. To date, 13 individual interviews and eleven group discussions have been conducted. In accordance with the principle of maximum contrast (Dimbath et al., 2018), students were selected who covered a diverse range of subjects in terms of the degree programmes they studied and who differed in terms of the type of higher education institution they attended in order to be able to capture the breadth of the student experience. The interview partners were selected on the one hand through personal contacts and on the other hand through external requests to the interview team. For publication as podcasts, the interviews, which were available as raw material, were edited and supplemented with moderation parts. They were then published on formatspecific websites and well-known podcast platforms and promoted via social media.

Aspects such as data selection and sampling as well as the quality of the data limit the validity of empirical studies (Baur \& Blasius, 2014; Häder, 2019). Due to self-selection effects, it is assumed that students who are more reticent regarding public statements might not even agree to participate in the interviews and that those who feel comfortable speaking in public are more likely to have their say. This is likely to be equally true for those students who are overwhelmed by their current study situation. With these limitations, it can be assumed that all study situations and challenges are represented to a very limited extent, which limits the validity of the qualitative material. 


\section{Analysis and processing of the results}

\section{Subjective preferences and quality requirements for higher education teaching in the shutdown}

Using the qualitative interview material, we first reconstruct what, from the learners' point of view, are preferences and quality requirements under conditions of digital higher education teaching. The coded segments of the qualitative interviews were assigned to subcodes (evaluative statements on forms of digital teaching; on framework conditions; statements on the topic of digital social presence; wishes and demands for current and future higher education teaching) and are analysed in this chapter with regard to information about their own learning preferences and the subjective reconstruction of their study situation. The investigation of subjective quality preferences was first conducted for learning in online settings by Ehlers (2004).

In our study, clear quality preferences of students could be evaluated in a differentiated way and quality potentials for digital teaching could be derived from this. Overall, it can be observed that the ongoing situation brings more framework conditions into view that influence the perceived quality of online teaching - therefore, subjective quality requirements increase with the duration of the pandemic situation. The qualitative statements show a picture of students who reconstruct the current study experience primarily in terms of the dimensions of flexibility, individualisation, personalisation and digital social presence. There are students who experience greater challenges with regard to the dimensions mentioned and others who currently find favourable study conditions for themselves with regard to these dimensions. The development of capacities, concepts and experiences in the area of digital social presence can be seen as a particularly important point. The following table relates subjectively perceived barriers, conducive conditions and potentials for quality in digital teaching and learning.

Table 1: $\quad$ Subjective reconstructions of quality requirements

\begin{tabular}{lll}
\hline Subjectively perceived barriers to quality & Subjectively perceived conducive conditions & Subjectively identified potentials \\
\hline $\begin{array}{l}\text { Discrepancy between differentiated quality } \\
\text { requirements of students and actual teaching }\end{array}$ & $\begin{array}{l}\text { Face-to-face lectures meet the need for } \\
\text { structure; asynchronous formats meet the need } \\
\text { for flexibility }\end{array}$ & $\begin{array}{l}\text { Richer learning environments and holistic } \\
\text { digitisation of courses that meet quality } \\
\text { requirements }\end{array}$ \\
$\begin{array}{l}\text { Stressful experience due to increased workload; } \\
\text { general conditions negatively influence the } \\
\text { need for equal participation in studies }\end{array}$ & $\begin{array}{l}\text { Need for support is met through organisational } \\
\text { flexibility and support services }\end{array}$ & $\begin{array}{l}\text { Good accessibility of contact persons as well as } \\
\text { individual support and solutions }\end{array}$ \\
$\begin{array}{l}\text { The need for social contacts and exchange is } \\
\text { not sufficiently met }\end{array}$ & $\begin{array}{l}\text { The need for social contacts is fulfilled in } \\
\text { individual cases, for example in group work; } \\
\text { exchanges at eye level with lecturers are } \\
\text { perceived as positive and fulfil the need for } \\
\text { respect and solidarity. }\end{array}$ & $\begin{array}{l}\text { Creating new solutions and space for digital } \\
\text { social presence }\end{array}$ \\
$\begin{array}{l}\text { Concern that teaching has not developed } \\
\text { further compared to before the pandemic }\end{array}$ & $\begin{array}{l}\text { Theaching is met by involving students and } \\
\text { reflecting on experiences made }\end{array}$ & $\begin{array}{l}\text { Maintain flexibility and openness and further } \\
\text { develop teaching with students }\end{array}$ \\
\hline
\end{tabular}


Eigbrecht, L., \& Ehlers, U.-D.

Reconstructing Subjective Study Experiences during Shutdown in Pandemic Times

\section{Participation opportunities and requirements in higher education teaching during the shutdown}

In her "Participative Media Didactics", Mayrberger describes that "the digitalisation of teaching and learning can only succeed if sufficient experiential spaces are provided for the relevant actors so that they can experience and authentically experience self-directed learning and participation - and critically relate to it" (Mayrberger, 2019; p.44). The depth of participation or involvement of actors is often classified using stage models (Arnstein, 1969; Wright, 2016). Füchtenhans et al. and other researchers describe that student participation and co-design in teaching and research are not yet established and taken for granted, even if this results in a better consideration of their interests and strengthens the personal responsibility and maturity of students for their learning process (Füchtenhans et al., 2018; Hofhues, 2013; Barrineau et al., 2019) in order to be able to address current and future challenges of higher education teaching (Mayrberger, 2020). This also corresponds to a subjective quality perspective described earlier, in which learners themselves are empowered in their responsibility for their learning process.

The forms of participation can be divided into more active and passive forms of participation. Furthermore, they can be divided into participation at the micro (learning, seminar), meso (institution) and macro level (educational initiatives, political level), examples of which can be found in the students' statements. The qualitative data shows that there is a strongly elaborated corpus of requirements for participation that concerns all organisational levels and is much differentiated in terms of participation levels and contexts. They are linked to values, attitudes and corresponding needs that students can articulate and demand more or less consciously through participation opportunities - be it in the joint design of (digital) teaching, in the involvement and co-determination in institutional strategic decisions or in supra-regional and political engagement. An awareness of the quality of higher education teaching seems to go hand in hand with a stronger active demand for it and participation in the design of teaching. The statements on participation opportunities and requirements are summarized in the following table. 
Eigbrecht, L., \& Ehlers, U.-D.

Reconstructing Subjective Study Experiences during Shutdown in Pandemic Times

Table 2: $\quad$ Statements on participation opportunities and requirements during the shutdown

\begin{tabular}{lll}
\hline \multicolumn{1}{c}{ Micro level } & \multicolumn{1}{c}{ Meso level } & Macro level \\
\hline \multicolumn{1}{c}{ Actively shaping: Now } & \\
\hline $\begin{array}{l}\text { Encouraging teachers to } \\
\text { co-designing teaching \& } \\
\text { learning }\end{array}$ & $\begin{array}{l}\text { Survey by student representatives with } \\
\text { recommendations to institutional } \\
\text { management; greater openness when } \\
\text { students want to place and advance issues; } \\
\text { digital engagement; visibility of organised } \\
\text { student participation has increased }\end{array}$ & $\begin{array}{l}\text { Petition for non-valuation } \\
\text { of the semester }\end{array}$ \\
\hline
\end{tabular}

Actively shaping: Future

Openness to be maintained Maintain; strengthen digital engagement supra-regionally; stronger organised student engagement

Passive: Now

Lecturers solicit feedback on how students feel and evaluate course design; participation in teaching not possible due to technical and social conditions
Professors approach student council to work out solutions together

Passive: Future

Lecturers should seek specific Include disadvantaged student groups in the feedback from students design of future teaching; transparent communication
Higher education teaching should become more inclusive, fair, student-centred and equal

\section{Description and reconstruction of own study strategies in the 'shutdown'}

The qualitative interview material can also be used to reconstruct statements about students' study and learning strategies with which students structure and organise their everyday study and learning process. The data show that studying in times of pandemic challenges students more on an individual level through spatial and social isolation, increases degrees of freedom and choices - and thus the potential for developing selforganisation and self-regulation (Probst, 1987), with which they influence or control actions and internal processes (Baumeister \& Vohs, 2004).

In the qualitative interviews, students make statements about subjective strategies with which they cope with the demands of their studies - it can be concluded that the awareness of corresponding competences increases due to the current situation. Students make statements about self-organisation strategies in relation to the organisation of their own everyday learning and studying, in relation to media use, which are gaining in importance through the digitalisation of teaching, as well as in relation to local conditions. The material shows that students know, reflect on and apply numerous self-organisation 
strategies and consider them significant. The challenges of digital study take increasingly place at the individual level, require more self-regulation and self-organisation and can thus also become a burden. Therefore, conditions that limit the effectiveness of these strategies are also mentioned. It can be deduced from this that studying has become an even more individual challenge and increasingly demands and expands self-organisation competences. The following table summarises the statements made by students on hindering and supporting factors with regard to self-organisation strategies:

Table 3: Hindering and facilitating factors for self-organisation

\begin{tabular}{lll}
\hline $\begin{array}{l}\text { Hindering factors for self- } \\
\text { organisation }\end{array}$ & $\begin{array}{l}\text { Facilitating factors for self- } \\
\text { organisation }\end{array}$ & Solutions \\
\hline $\begin{array}{l}\text { Delayed or un-regular provision } \\
\text { of learning materials }\end{array}$ & $\begin{array}{l}\text { Conscious routines and learning } \\
\text { plans }\end{array}$ & $\begin{array}{l}\text { Importance of self-organisation } \\
\text { strategies increases }\end{array}$ \\
$\begin{array}{ll}\text { Media distractions } \\
\text { tools considered helpful }\end{array}$ & $\begin{array}{l}\text { Necessity of a strategic learning } \\
\text { approach in relation to media use }\end{array}$ \\
$\begin{array}{l}\text { Distraction due to disturbances } \\
\text { and work in the household; } \\
\text { problematic spatial restriction }\end{array}$ & $\begin{array}{l}\text { Focusing and immersion easier at } \\
\text { home }\end{array}$ & $\begin{array}{l}\text { Deliberate spatial separation of } \\
\text { living and working space; } \\
\text { Redesigning spaces and using } \\
\text { them creatively }\end{array}$ \\
$\begin{array}{l}\text { Increased workload; mental } \\
\text { stress; challenges at individual } \\
\text { level }\end{array}$ & $\begin{array}{l}\text { Experience in self-organisation } \\
\text { and self-learning }\end{array}$ & \begin{tabular}{l} 
Support services \\
\hline
\end{tabular}
\end{tabular}

\section{Summary and conclusion}

Due to the special study situation, students in the shutdown have become familiar with different ways in which studying is possible. By reflecting on what constitutes good teaching for them, students become aware of individual quality dimensions and requirements - and perceive strengths and weaknesses of different teaching settings. Furthermore, they articulate the extent to which they use conscious self-organisation strategies to organise their daily study routine, which can be individually professionalised through support services. Through close exchange with lecturers, students could often communicate or demand their own preferences and wishes. Higher education institutions can use these new participatory competences and benefit from student perspectives in order to jointly design future teaching and learning processes in participatory settings. In addition to numerous challenges, the pandemic has thus also brought forth the potential of students to shape their learning processes in a self-determined and self-organised way, to reflect on them and to contribute to shaping future higher education teaching and learning as experts. This is a strong signal for including students' voices in the debate on higher education in times of Covid-19 and in the future to provide quality education accessible to all. 


\section{References}

Arnstein, S. R. (1969). A Ladder of Citizen Participation. Journal of the American Institute of Planners, 35(4), 216-224. https://doi.org/10.1080/01944366908977225

Barnat, M., Hofhues, S., Kenneweg, A. C., Merkt, M., Salden, P., \& Urban, D. (Eds.) (2013). ZHW-Almanach: Vol. 1. Junge Hochschul- und Mediendidaktik. Forschung und Praxis im Dialog. Hamburg.

Barrineau, S., Engström, A., \& Schnaas, U. (2019). An active student participation companion. https://doi.org/10.23865/hu.v9.1734

Baumeister, R. F., \& Vohs, K. D. (Eds.) (2004). Handbook of self-regulation: Research, theory, and applications. New York, NY: Guilford Press. Retrieved from http://www.loc.gov/catdir/description/guilford051/2003020013.html

Baur, N., \& Blasius, J. (2014). Handbuch Methoden der empirischen Sozialforschung. Wiesbaden: Springer Fachmedien Wiesbaden. https://doi.org/10.1007/978-3-53118939-0

Dimbath, O., Ernst-Heidenreich, M., \& Roche, M. (2018). Praxis und Theorie des Theoretical Sampling. Methodologische Überlegungen zum Verfahren einer verlaufsorientierten Fallauswahl. Advance online publication. https://doi.org/10.17169/FQS-19.3.2810

Ehlers, U.-D. (2004). Qualität im E-Learning aus Lernersicht. Wiesbaden: VS Verlag für Sozialwissenschaften. https://doi.org/10.1007/978-3-663-11211-2

Füchtenhans, S., Koch-Thiele, A., Witt, T., \& Zilles, K. (2018). Förderung studentischer Partizipation am Beispiel einer hochschuldidaktischen Tagung. Die Hochschullehre, 4, 345-360.

Gestung, V., Hettler, I. S., Badermann, M., Deuer, E., \& Meyer, T. (2021). Online-Lehre während der COVID-19-Pandemie: Die studentische Perspektive. Forschungsbericht 7/2021. Retrieved from

https://www.dhbw.de/fileadmin/user_upload/Dokumente/Schrifterzeugnisse/Forsch ungsbericht_7_2021_Online-Lehre_waehrend_der_COVID-19-Pandemie.pdf

Grabowski, J., Smith, E. E., \& Nolen-Hoeksema, S. (Eds.) (2007). Atkinsons und Hilgards Einführung in die Psychologie ([2. Aufl., Übers. und Adaption der amerikan.] 14. Aufl.). Heidelberg: Spektrum Akad. Verl. Retrieved from http://deposit.d-nb.de/cgibin/dokserv?id=2966314\&prov=M\&dok_var=1\&dok_ext=htm

Häder, M. (2019). Empirische Sozialforschung. Wiesbaden: Springer Fachmedien Wiesbaden. https://doi.org/10.1007/978-3-658-26986-9 
Hofhues, S. (2013). Offenheit als Stolperstein: Partizipation mit und an Hochschullehre. In M. Barnat, S. Hofhues, A. C. Kenneweg, M. Merkt, P. Salden, \& D. Urban (Eds.), ZHW-Almanach: Vol. 1. Junge Hochschul- und Mediendidaktik. Forschung und Praxis im Dialog (pp. 161-166). Hamburg. https://doi.org/10.3278/HSL1314W

Marczuk, A., Multrus, F., \& Lörz, M. (2021). Die Studiensituation in der CoronaPandemie. Auswirkungen der Digitalisierung auf die Lern- und Kontaktsituation von Studierenden. https://doi.org/10.34878/2021.01.DZHW_BRIEF

Mayrberger, K. (2019). Partizipative Mediendidaktik: Gestaltung der (Hochschul-) Bildung unter den Bedingungen der Digitalisierung.

Mayrberger, K. (2020). Jahrbuch Medienpädagogik 17: Lernen mit und über Medien in einer digitalen Welt. MedienPädagogik: Zeitschrift Für Theorie Und Praxis Der Medienbildung, 17(Jahrbuch Medienpädagogik), 59-92. https://doi.org/10.21240/mpaed/jb17/2020.04.26.X

Mayring, P. (2015). Qualitative Inhaltsanalyse: Grundlagen und Techniken (12., überarb. Aufl.). Beltz Pädagogik. Weinheim: Beltz. Retrieved from http://contentselect.com/index.php?id=bib_view\&ean=9783407293930

Nascimbeni, F., \& Ehlers, U. D. (2020). Open teaching: Research and practice on open, innovative and engaging pedagogies: Editorial. Journal of E-Learning and Knowledge Society, 16(4), I-IV. https://doi.org/10.20368/1971-8829/1135423

Probst, G. J. B. (1987). Selbst-Organisation: Ordnungsprozesse in sozialen Systemen aus ganzheitlicher Sicht. Biologie und Evolution interdisziplinär. Berlin: Parey.

Traus, A., Höffken, K., Thomas, S., Mangold, K., \& Schröer, W. (2020). Stu.diCo. Studieren digital in Zeiten von Corona. https://doi.org/10.18442/150

Wright, M. T. (2016). Partizipation: Mitentscheidung der Bürgerinnen und Bürger. https://doi.org/10.17623/BZGA:224-I084-1.0 